\title{
Cytotoxic effects of polysaccharides isolated from Emilia sonchifolia in cervical cancer cell line
}

\author{
Thulasi G Pillai ${ }^{1}$, Dinesh Raghu ${ }^{2}$ and D Karunagaran ${ }^{2}$ \\ ${ }^{1}$ Department of Forest Pathology, Kerala Forest Research Institute, Peechi, Thrissur-680651, Kerala, India \\ ${ }^{2}$ Indian Institute of Technology Madras, Adayar, Chennai- 600036, Tamilnadu, India
}

\begin{abstract}
Polysaccharides (PS) were isolated from the edible, medicinal plant, Emilia sonchifolia. Cytotoxicity activities of the polysaccharides were studied by MTT assay in human cervical cancer cell lines (HeLa). PS decreased the viability of $\mathrm{HeLa}$ cells, and the $\mathrm{IC}_{50}$ value was found to be $40 \mu \mathrm{g} / \mathrm{ml}$ for $\mathrm{HeLa}$ cells at $48 \mathrm{~h}$ in a concentration dependent manner. Intracellular reactive oxygen species level was increased by PS in a concentration dependent manner which is the suggested mechanism of action. Further studies on anticancer activities of the compound are in progress.
\end{abstract}

\section{Introduction}

Natural products are important in drug development programme. About half of the clinical drugs available today are of natural product origin. Emilia sonchifolia (L.) DC (Compositae), an herbaceous plant found in Taiwan and India, is used as folk medicine [1]. Emilia sonchifolia has also been reported to possess anti-fever activities [2,3] antimicrobial activity [4] analgesic and anti-inflammatory activities [5-7], anticancer activities [8-10] antioxidant activities [11-14], antidiabetic[15]; anti-cataract activities Asije, Couto, Gao, Cheng et al. [1619] anticonvulsant activity [20]. The aerial part of the plant has been reported to contain alkaloids [21] flavonoids, and terpenes [22]. Emilia sonchifolia extract, is reported to contribute to apoptosis through p53mediated ATM/Fas signalling activating both extrinsic and intrinsic pathways in HCT 116 human colorectal cancer cells [23]. Emilia sonchifolia is used as a salad plant before flowering and the leaves and stem are used as vegetable [24].

Cervical cancer is the fourth common cause of death from cancer in women worldwide [25]. 70\% of cervical cancers occur in developing countries. It was estimated that there were 528,000 cases of cervical cancer and 266,000 deaths in 2012 [26]. This is about $8 \%$ of the total cases and total deaths from cancer. In low income countries it is the most common cause of cancer death. In developed countries, the widespread use of cervical screening programs has dramatically reduced rates of cervical cancer [27]. Polysaccharides are reported to possess antitumor properties. For example, lentinan which is a beta-1-6, glucan produced from Shiitake mushroom, Lentinus edodes, possess anticancer effect against human carcinomas [28]. Our earlier studies have revealed that polysaccharides isolated from the medicinal mushroom, Ganoderma lucidum, possess capacity of enhancing DNA repair in human lymphocytes [29].

The traditional claims enthused us to select the plant for this study. We isolated polysaccharides (PS) from Emilia sonchifolia and studied its cytotoxicity and antioxidant activity in HeLa cervical cancer cell line.

\section{Materials and methods}

\section{Chemicals}

All the chemicals were obtained from Merck Genei, Bangalore.

\section{Isolation of polysaccharides}

Whole plant material was collected from the outskirts of Thrissur, Kerala, India. The polysaccharides were isolated from the leaves and stem by the method of Mizuno [30], with slight modifications. The water extract obtained after boiling leaves and stem of the plant were filtered and concentrated to about one third of its original volume and chilled ethanol about 5 times the volume of the extract was added and kept at $4^{\circ} \mathrm{C}$ for $48 \mathrm{hrs}$. The extract was centrifuged at low temperature. The precipitate obtained was dissolved in water and reprecipitated with equal volume of cetyltrimethyl ammonium hydroxide and kept for overnight. The supernatant was separated again and precipitated with chilled ethanol. After centrifugation, the precipitate obtained was dried and loaded on a DEAE cellulose column and eluted with deionised water $(25$ $\mathrm{ml}$ fractions). The polysaccharide fraction was tested with Phenol sulphuric acid reagent [31] for confirmation. The fraction was then evaporated at low temperature and lyophilized to obtain a light brown powder. Further characterization of the compound was done by IR, NMR and ESR analysis. The compound was dissolved in double distilled water for the studies.

\section{Cell culture}

Human cervical cancer cell line, HeLa were maintained as adherent monolayers in a tissue culture flask with complete DMEM (GIBCO)

Correspondence to: Dr. D.Karunagaran, Professor and Head, Department of Biotechnology, IIT Madras, Adayar, Chennai, Tamilnadu, India, E-mail: karunagarand@gmail.com

Thulasi G Pillai, Department of Forest Pathology, Kerala Forest Research Institute, Peechi, Thrissur-680651, Kerala, India, E-mail: thulasigpilla@yahoo.co.in

Key words: polysaccharides, emilia, cervical cancer, HeLa cell line, MTT assay, ROS assay

Received: July 27, 2017; Accepted: August 18, 2017; Published: August 21, 2017 
supplemented with $10 \%(\mathrm{v} / \mathrm{v})$ fetal bovine serum (FBS) containing 100 $\mathrm{mg} / \mathrm{l}$ penicillin and $66.6 \mathrm{mg} / \mathrm{l}$ streptomycin. Cells were incubated in a humidified incubator at $37^{\circ} \mathrm{C}$ with $5 \% \mathrm{CO}_{2}$. During the experiment, the cells were washed using 1XPBS-EDTA, trypsinized using $0.25 \%$ trypsin, neutralized with complete DMEM, centrifuged at $1500 \mathrm{rpm}$ for $5 \mathrm{~min}$, and the supernatant was aspirated whereas the pellet was suspended in complete DMEM for seeding or culturing.

\section{Cytotoxicity assay}

Cell viability was assessed using MTT (3-(4, 5-dimethylthiazol2-yl)-2, 5-diphenyl tetrazolium bromide) dye. Briefly, 5000 cells/well were seeded in 96-well plates and allowed to adhere overnight. Cells were treated with different concentrations $(25-250 \mu \mathrm{g} / \mathrm{ml})$ of PS from E.sonchifolia for $48 \mathrm{~h}$, and MTT $(5 \mathrm{mg} / \mathrm{mL})$ was added, incubated for $3.5 \mathrm{~h}$, followed by aspiration of the medium and solubilization of the formazan crystals by adding dimethyl sulfoxide (DMSO). After $5 \mathrm{~min}$, the color developed was read as an optical density (OD) using a BioRad 680 model colorimeter at $570 \mathrm{~nm}$ with $655 \mathrm{~nm}$ as background reference.

\section{Reactive Oxygen Species (ROS) assay}

HeLa cells ( 15000 cells) were seeded on 96 well/plates were treated with various concentrations $(25-250 \mu \mathrm{g} / \mathrm{ml})$ of PS from E.sonchifolia for $24 \mathrm{~h}$. Media was completely removed and the cells were washed with 1X Phosphate buffer saline (PBS). Stock solution of $20 \mathrm{mM}$ Dichloro-dihydro-fluorescein diacetate (DCFH-DA) was prepared in dimethyl sulfoxide (DMSO). DCFH-DA was diluted in 1XPBS (1:2000) to make working concentration of $5 \mu \mathrm{M}$. To the each well, $50 \mu \mathrm{l}$ of the DCFH-DA and incubated at $37^{\circ} \mathrm{C}$ in dark for $30 \mathrm{~min}$. Then, DCFHDA is removed and $100 \mu \mathrm{l}$ of $1 \mathrm{XPBS}$ was added to each well and read at $480 \mathrm{~nm}$ (excitation wavelength) and $530 \mathrm{~nm}$ (emission wavelength). Simultaneously, cell viability was performed using alamar blue and normalized with the ROS readings.The assay was performed at least three independent experiments, each comprising no less than four replicates.

\section{Results}

The polysaccharides isolated from G.lucidum answered phenol sulphuric acid tests giving typical colour reactions indicating the presence of carbohydrates. Three absorption bands characteristic of ( $\mathrm{H}-\mathrm{O}-\mathrm{H}$ bending) $1637 \mathrm{~cm}$.sup.-1, $(\mathrm{OH}) 3448.64 \mathrm{~cm}$.sup. -1 and $(\mathrm{C}=\mathrm{O}$ bond) $1636.83 \mathrm{~cm}$.sup.-1 were observed. The band between 1000-1100 $\left(1110 \mathrm{~cm}^{-1}\right)$ is characteristic for the presence of beta-glucan. In the HNMR spectrum, H.sup.-1 signals were observed at less than $4.8 \mathrm{ppm}$ $(4.685,4.682,4.677 \mathrm{ppm})$, which suggest that component sugars have beta $(1,6)$ configuration.

PS decreased the viability of HeLa cells, and the $\mathrm{IC}_{50}$ value was found to be $40 \mu \mathrm{g} / \mathrm{ml}$ for HeLa cells at $48 \mathrm{~h}$ (Figure 1) in a concentrationdependent manner. The intracellular levels of reactive oxygen species (ROS) production were measured using DCFH-DA. PS increases the production of ROS in HeLa cells in a concentration dependent manner (Figure 2). The result suggests that PS induces ROS production in HeLa cells which could be one of the mechanism through which it exerts its cytotoxic effect [32].

\section{Discussion}

It has been reported that the alcohol extract of this plant (aerial part) has cytotoxicity, as well as anti Ehrlich ascitic carcinoma (EAC) and anti-Dalton's lymphoma ascites (DLA) activities in mice. Polysaccharides are the major components of water extract.

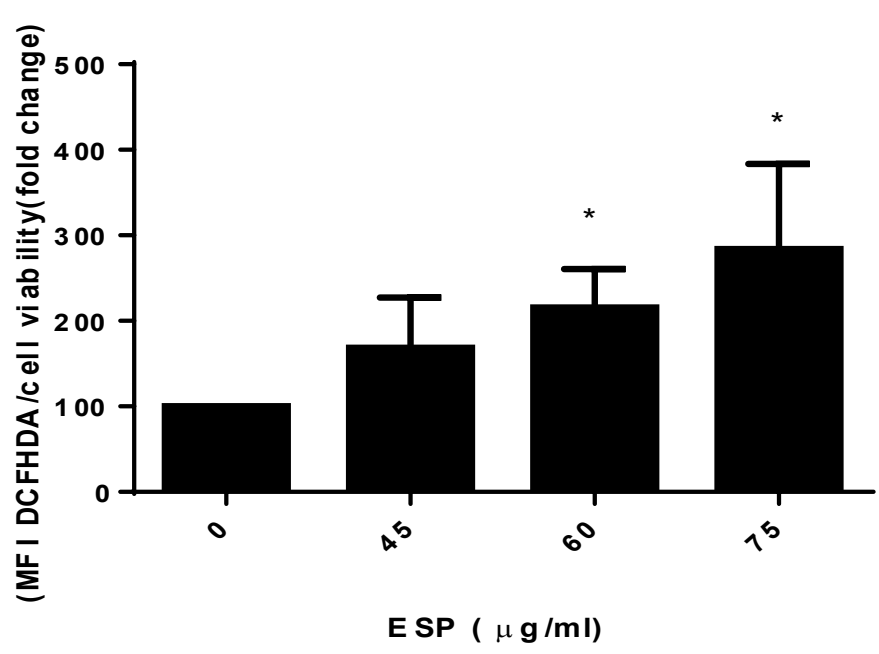

Figure 1. Effect of ESP on reactive oxygen species in HeLa cells

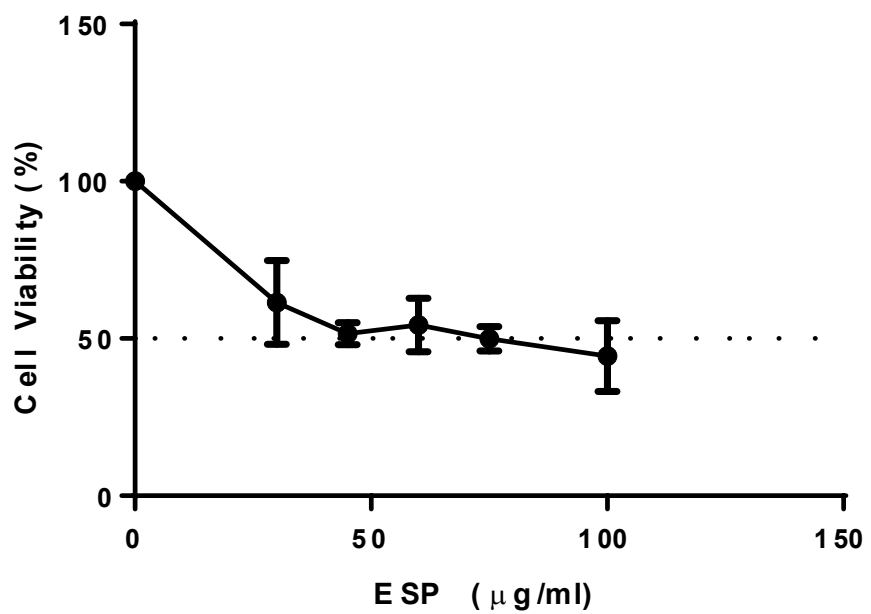

Figure 2. Effect of ESP on viability of HeLa cells

The ability of bioactive polysaccharides and polysaccharide-bound proteins to modulate so many important immune cells may due to the structural diversity and variability of these macromolecules. Unlike proteins and nucleic acids, polysaccharides contain repetitive structural features which are polymers of monosaccharide residues joined to each other by glycosidic linkages [33]. Among these macromolecules, polysaccharides offer the highest capacity for carrying biological information because they have the greatest potential for structural variability. For example, the number of possible permutations for four different sugar monomers can be up to 35,560 unique tetrasaccharides, whereas four amino acids can form only 24 different permutations [33]. Therefore, this enormous potential variability in polysaccharide structure gives the necessary flexibility for the precise regulatory mechanisms of various cell-cell interactions in higher organisms. Evidence suggest that the activity of polysaccharides is also dependent on their conformation, composition and size, with high molecular weight fraction being more active, while fractions with low molecular weight from same source show no activity [34].

Chemical modification is often carried out to improve the antitumor activity of polysaccharides and their clinical qualities (mostly water solubility). Their activity is especially beneficial in clinics when used in conjunction with chemotherapy. 
Reactive oxygen species play an important role in apoptosis. In apoptotic process an increase in cellular Reactive oxygen species (ROS) production is often observed enhanced by various stimuli like APO1/Fas/CD95 ligands [35-42]. Increased ROS concentrations stimulate apoptotic cell death in various cell types [43,44], suggesting that ROS contribute to cell death subject to their generation in the context of the apoptotic process.

Herbal polysaccharides are natural compounds with much therapeutic potential. Continued advancements in our understanding of particular structure-function relationships and polysaccharidespecific receptors should provide a foundation for the further development of these compound that have novel cytotoxic activity. As Emilia sonchifolia is a medicinal plant its application in disease management will be a promising approach.

\section{Acknowledgement}

The author is grateful to people of SAIF, IIT Mumbai for helping in getting the structural details of the compound.

\section{References}

1. Yoga Latha L, Darah I, Sasidharan S, Jain K (2009) Antimicrobial Activity of Emilia sonchifoliaDC.,Tridaxprocumbens L. and Vernoniacinerea L. of Asteracea Family: Potential as Food Preservatives. Malaysia Journal Nutrition 15: 223-231.

2. Rahman A, Akter N, Rashid H, Ahmed NU, Uddin N, et al. (2012) Analgesic and antiinflammatory effect of whole Ageratum conyzoides and Emilia sonchifolia alcoholic extracts in animal models. African Journal of Pharmacy and Pharmacology 6: 14691476.

3. Muko KN, Ohiri FC (2000) A preliminary study on the anti-inflammatory properties of Emilia sonchifolia leaf extracts. Fitoterapia 71: 65-68. [Crossref]

4. Shylesh BS, Padikkala J (2000) In vitro cytotoxic and antitumor property of Emilia sonchifolia (L.) DC in mice. J Ethnopharmacol 73: 495-500. [Crossref]

5. Cibin TR, Srinivas G, Gayathri Devi D, Srinivas P, Lija Y, et al. (2006) Antioxidant and Antiproliferative Effects of Flavonoids from Emilia sonchifolia Linn on Human Cancer Cells. International Journal of Pharmacology 2: 520-524.

6. Jiny Varghese K, Anila J, Nagalekshmi R, Resiya S, Sonu J (2010) Dasapushpam: The Traditional Uses and The Therapeutic Potential of Ten Sacred Plants Of Kerala State In India. International Journal of Pharmaceutical Sciences and Research 1: 50-59

7. Shyura L, Tsunga J, Chenb J, Chiua C, Lo C (2005) Antioxidant Properties of Extracts from Medicinal Plants Popularly Used in Taiwan. International Journal of Applied Science and Engineering 3: 195-202.

8. Guha G, Rajkumar V, Mathew L, Kumar RA (2011) The antioxidant and DNA protection potential of Indian tribal medicinal plants. Turkish Journal Biology: 233 242 .

9. Sophia D, Ragavendran P, Arulraj C, Gopalakrishnan VK (2011) In vitro antioxidan activity and HPTLC determination of n-hexane extract of Emilia sonchifolia (L.) DC. J Basic Clin Pharm 002: 179-183.

10. Raj M (2012) Natural Antioxidant (Flavone Glycoside) From Emilia Sonchifolia Dc. and Its Potential Activity. International Journal of Pharmacy and Pharmaceutical Sciences 4: 159-162.

11. Monago CC, Gozie GC, Joshua PE (2010) Antidiabetic and Antilipidemic Effects of Alkaloidal Extract of Emilia sonchifolia in Rat. Research Journal of Science and Technology 2010; 51.

12. Lija Y, Biju PG, Reeni A, Cibin TR, Sahasranamam V, et al. (2006) Modulation of selenite cataract by the flavonoid fraction of Emilia sonchifolia in experimental animal model. Phytotherapy Res 20: 1091-1095.

13. Patel DK, Prasad SK, Kumar R, Hemalatha S (2011) Cataract: A major secondary complication of diabetes, its epidemiology and an overview on major medicinal plants screened for anti-cataract activity. Asian Pacific Journal of Tropical Disease: 323-329.

14. Patel P, Jivani N, Malaviya S, Gohil T, Bhalodia Y (2012) Cataract: A major secondary diabetic complication. International Current Pharmaceutical Journal 1: 180-185.

15. Singh B, Kumar D, Singh R (2012) Phytotherapeutics for management and prevention of cataract generation. Phytopharmacology 3: 93-110.
16. Asije O, Adelusi SA, Usifoh CO (2006) Anticonvulsant Activity of Emilia sonchifolia Leaf Extracts. Pakistan Journal of Scientific and Industrial Research 49: 269.

17. Couto VM, Vilela FC, Dias DF, Dos Santos MH, Soncini R, et al. (2011) Antinociceptive effect of extract of Emilia sonchifolia in mice. J Ethnopharmacol 134: 348-353. [Crossref]

18. Gao JJ, Cheng DL, Liu XP (1993) Chemical constituents of Emilia sonchifolia L. DC] Zhongguo Zhong Yao Za Zhi 18: 102-103, 127. [Crossref]

19. Cheng D, Röder E (1986) Pyrrolizidine Alkaloids from Emilia sonchifolia. Planta Med: 484-486. [Crossref]

20. Ogbonnia SO, Mbaka GO, Anyika EN, Emordi JE, Nwakakwa N (2011) An Evaluation of Acute and Subchronic Toxicities of a Nigerian Polyherbal Tea Remedy. Pakistan Journal of Nutrition 10: 1022-1028

21. Cheng D, Roder E (1984) Pyrrolizidin alkaloids of Emilia sonchifolia. Planta Medica 6: 484-486.

22. Srinivasan KK, Subramanian SS (1980) Phytochemical screening of Emilia sonchifolia. Fitoterapia 51: 241-242.

23. Lan Y, Chiang J, Huang W, Lu C, Chung J, et al. (2012) Hindawi Publishing Corporation, New York, USA. Evidence-based Complementary and Alternative Medicine 46.

24. Yadava RN, Mamta R (2012) Antiviral activity of a new flavone glycoside from Emilia sonchifolia DC. Indian Journal of Chemistry: 635-638.

25. World Cancer Report (2014) World Health Organization. 2014. Chapter 5.12. ISBN 9283204298 .

26. World Health Organization (2014). Fact sheet No. 297: Cancer.

27. Canavan TP, Doshi NR (2000) Cervical cancer. Am Fam Physician 61: 1369-1376. [Crossref]

28. Chihara G, Hamuro J, Meada Y, Arai Y, Fukuoka F (1970) Fractionation and purification of polysaccharides with marked antitumor activity, especially Lentinan from Lentinusedodes (Bark) sing, an edible mushroom. Cancer Res 30: 2776-2781.

29. Thulasi GP, Nair CKK, Janardhanan KK (2010) Enhancement of repair of radiation induced DNA strand breaks in human cells by Ganoderma mushroom polysaccharides. Food chemistry 119: 1040-1043.

30. Mizuno T (2000) Development of an antitumor biological response modifier from Phellinus linteusTeng. (Review). Int J Med Mushrooms 2: 21-33.

31. Dubois SM, Gilles GA, Hamilton JK (1956) Colourimetric estimation of Carbohydrates by Phenol Sulphuric acid method. Anal Chem 28: 350-356.

32. The wealth of India: First Supplement Series. NISC CSIR, India.

33. Ooi CVE, Liu F (2000) Immunomodulation and Anti-Cancer Activity of PolysaccharideProtein Complexes. Current Medicinal Chemistry 7: 715-729.

34. Bohn JA, BeMiller JN (1995) (1-3)-B-D-Glucans as biological response modifiers: a review of structure-functional activity relationships. Carbohydrate Polymers 28: 3-14

35. Banki K, Hutter E, Gonchoroff NJ, Perl A (1999) Elevation of mitochondrial transmembrane potential and reactive oxygen intermediate levels are early events and occur independently from activation of caspases in Fas signaling. J Immunol 162: 1466-1479.

36. Esteve JM, Mompo J, de la Asuncion JG, Sastre J, Asensi M, et al. (1999) Oxidative damage to mitochondrial DNA and glutathione oxidation in apoptosis: studies in vivo and in vitro. FASEB $J$ 13: 1055-1064.

37. Hockenbery DM, Oltvai ZN, Yin XM, Milliman CL, Korsmeyer SJ (1993) Bcl-2 functions in an antioxidant pathway to prevent apoptosis. Cell 75: 241-251. [Crossref]

38. Johnson TM, Yu ZX, Ferrans VJ, Lowenstein RA, Finkel T(1996) Reactive oxygen species are downstream mediators of p53-dependent apoptosis. Proc Natl Acad Sci USA 93:11848-11852.

39. Korsmeyer SJ (1995) Regulators of cell death. Trends Genet 11: 101-105. [Crossref]

40. Um HD, Orenstein JM, Wahl S (1996) Fas mediates apoptosis in human monocytes by a reactive oxygen intermediate dependent pathway. J Immunol 156: 3469-3477.

41. Williams MS, Henkart PA (1996) Role of reactive oxygen intermediates in TCRinduced death of T cell blasts and hybridomas. J Immunol 157: 2395-2402. [Crossref]

42. ZamzamiMarchetti NP, Castedo M, Decaudin D, Macho A, Hirsch T, et al. (1995) Sequential reduction of mitochondrial transmembrane potential and generation of reactive oxygen species in early programmed cell death. J Exp Med 182: 367-377. 
Pillai TG (2017) Cytotoxic effects of polysaccharides isolated from Emilia sonchifolia in cervical cancer cell line

43. Dumont A, Hehner SP, Hofmann TG, Ueffing M, Dröge W, Schmitz ML(1999) Hydrogen peroxide-induced apoptosis is CD95-independent, requires the release of mitochondria-derived reactive oxygen species and the activation of NF-?B. Oncogene 18: 747-757.
44. Slater AF, Stefan C, Nobel I, van den Dobbelsteen DJ, Orrenius S (1995) Signalling mechanisms and oxidative stress in apoptosis. Toxicol Lett 82-83: 149-53. [Crossref]

Copyright: (C2017 Pillai TG. This is an open-access article distributed under the terms of the Creative Commons Attribution License, which permits unrestricted use, distribution, and reproduction in any medium, provided the original author and source are credited. 